\title{
Leprosy in Cross River State, Nigeria
}

\author{
IRENE BRIGHTMER \\ Geography Division, Derbyshire College of Higher Education, \\ Western Road, Mickleover, Derby DE3 $5 G X$
}

\section{Accepted for publication 17 June 1986}

\begin{abstract}
Summary This spatial study of leprosy was stimulated by reports of medical workers in the State that serious and advanced cases of the disease are appearing, and that possibly there are pockets of infection which need to be identified and taken into account by the State's Leprosy Control Programme.

A preliminary examination of the spatial pattern of leprosy in the State is presented here, and shows higher prevalence rates for the disease in the areas of sparsest population. The work is continuing, and will attempt to explain these distribution features.

An account is given of some prevailing local attitudes to leprosy and their consequences for the control of the disease. The structure of the control service (State and Federal) is outlined, and constraints limiting its effectiveness are discussed.
\end{abstract}

\section{Introduction}

Cross River State, one of the 19 states of the Federal Republic of Nigeria, is located in the southeastern corner of the country, adjacent to the Republic of the Cameroons. It encompasses about $29,000 \mathrm{~km}^{2}$ between latitudes $4^{\circ} \mathrm{N}$ and $7^{\circ} \mathrm{N}$. In the last official census of the country in 1963 the recorded population was $3.5 \mathrm{M}$, and official projections estimate a current population (1986) exceeding $6 \mathrm{M} .^{1}$

The state lies wholly within the tropical zone but the northern area, the Obudu Plateau, over $1200 \mathrm{~m}$ high, is temperate. There are two seasons: the rainy season from May to October and the dry season from November to April, but along the coast no month is completely dry. Summer rainfall totals $3500 \mathrm{~mm}$ in the south-east and decreases northwards, but there are no water shortage problems. During the dry season, the relatively cool and very dry dust-laden Harmattan wind blows from the north, its effect decreasing towards the coast.

The economic mainstay of the State has always been its agriculture except on the coast where fishing is important, and the population of the state is predominantly rural. The staple food crops are roots (yam and cassava), supplemented by maize and plantains. Cash crops, especially palm oil, rubber and cocoa are produced by small farmers in the south, and also by large scale plantations mainly in Odukpani and Akamkpa. Since most of the state lies within the tsetse fly belt, meat is 
expensive. Fish is available in the south and is preferred but is rare in the north. Protein and iron deficiency are common nutritional problems among all sections of the population. Malnutrition, especially seasonally, is very serious in many village communities.

Petroleum is drilled offshore near Eket but has done little to transform the economy of Cross River State. Revenues go direct to the Federal Government and the industry employs only a few personnel who form a privileged enclave in Eket, a town with poor transport links with the rest of State, and without reliable mains water or electricity. One major impact of oil has been the disruption of the traditional fishing industry of the coastal area, sending fishermen further afield to less disturbed and less polluted waters, especially eastwards to the Cameroons.

Calabar is the State capital and the main industrial and employment centre in the State. There is a limited flow of people from the rest of the state for employment and education, but it has none of the usual "shanty town" developments of other African cities, and its growth is relatively controlled. However, severe overcrowding does exist in the older parts of the city due to natural rates of population increase among the indigenous Efik people.

The State is divided into 17 Local Government Areas for administration from the State capital each with its own Headquarters (map 1). These LGA headquarters in the densely populated south are dynamic towns with industries and factories of their own. Those in the sparsely populated north of the state are hardly more than villages with only the basic administrative functions which include the Leprosy Control Units. The southern part of the State has some of the highest rural population densities in West Africa and this pressure on agricultural resources has led to regular outmigration especially of young males. Their destinations are less populated areas of their own State, notably Akamkpa and also the Cameroons and formerly Fernando Po offshore, all for the purpose of agricultural labouring. The migration is far from permanent, being seasonal or at most of only a few years' duration. Such movements are significant in leprosy control, especially in view of the movement across the international border with the Cameroons, recently re-opened (February 1986). These agricultural labourers as well as the increasingly mobile offshore fishermen are represented among the leprosy cases studied.

\section{The leprosy problem}

There are 8000 registered cases of leprosy in Cross River State and it is by no means one of the worst states of Nigeria. In 1975 it was ranked only 8th out of the 19 states of the Federation for leprosy prevalence rates, ${ }^{2}$ and one state had a rate 10 times higher. The average prevalence rate for the state is approximately 1.3 registered cases per thousand people. This relatively low figure requires qualification on two grounds. It has been estimated that actual cases in CRS are double the number registered (whereas in some northern states in Nigeria it is believed that actual cases are half of those registered). ${ }^{3}$ The explanation is probably related to the heavy stigmatization of leprosy in CRS (see below). The second qualification is that the 1.3 per thousand average prevalence masks great variations within the State. Prevalence rates calculated (Table 1) and mapped foreach LGA (Figure 1) help to demonstrate this, but there are also known to be pockets of high prevalence within LGA's but these await further identification and study. Meanwhile, the map and table show rates by LGA varying from only 0.12 in Eket in the coastal area to 10.90 in Obudu. This reflects the popular perception of leprosy among people in the south of the State that 'it is much worse in the north'.

It is easy to recognize the association in the State of areas of highest leprosy prevalence with areas of lowest population density, and vice versa (Figures 1 and 2). A similar association has been noted elsewhere in Africa as well as in Nigeria. ${ }^{4}$ The explanations for such an association are not obvious. Population density may be a direct or indirect variable in the situation. Indirectly it may indicate the function of better infrastructure, modernization, better housing, higher standard of living etc. which are to be expected in areas of denser settlement and which have also been associated 
Table 1. Cross River State: leprosy prevalence per 1000 population by local government area, 1984.

\begin{tabular}{clr}
\hline Rank & LEA & Prevalence \\
\hline 1 & Obudu & $10 \cdot 90$ \\
2 & Ogoja & $10 \cdot 11$ \\
3 & Ikom & $4 \cdot 89$ \\
4 & Etinan & $1 \cdot 29$ \\
5 & Akamkpa & $1 \cdot 29$ \\
6 & Obubra & $1 \cdot 04$ \\
7 & Calabar Municipality & $0 \cdot 83$ \\
8 & Ukanafun & $0 \cdot 43$ \\
9 & Odukpani & $0 \cdot 43$ \\
10 & Itu & $0 \cdot 42$ \\
11 & Abak & $0 \cdot 34$ \\
12 & Ikot Ekpene & $0 \cdot 33$ \\
13 & Ikono & $0 \cdot 28$ \\
14 & Ikot Abasi & $0 \cdot 27$ \\
15 & Uyo & $0 \cdot 26$ \\
16 & Oron & $0 \cdot 21$ \\
17 & Eket & $0 \cdot 12$ \\
\end{tabular}

with improvements in the leprosy situation. So population density here may be a surrogate for economic development.

Etinan, ranked highest in population density Table 3, may be expected therefore to have the lowest prevalence rate and may seem an anomaly in having a prevalence of 1.29 per 1000 . But the map (Figure 3) shows that it has the only leprosy hospital in the south of the State and so it attracts patients from all the neighbouring LGA's as well as from Rivers State, which is particularly poorly served with leprosy services. So this inflates both prevalence and also incidence rates for Etinan LGA. Similarly, the clinic in Calabar attracts patients from neighbouring LGA's due to its accessibility and also for the anonymity it offers and so its prevalence rate is inflated.

The number of new cases registering in the whole State in 1984 was in excess of 300 . This gives an overall incidence rate of 0.05 new cases per 1000 population. The rate varies between LGA's and approximately matches the rank order of prevalence rates. However, there is a higher than expected incidence rate in Ikot Ekpene, which requires further investigation, especially as new cases were reporting not only to the local unit but also to the Etinan leprosy hospital right into 1986.

Of the total new cases, one quarter were diagnosed as lepromatous. Children under 15 years represented two fifths of all new cases. The numbers of male and female new cases were similar. (But a noticeable feature is the dominance of total female patients registered in the State. They make up $60 \%$ of all registered cases under 40 years, but in the $40+$ agegroup male and female cases are equal. Conversely, male in-patients outnumber female in all age groups.)

\section{Attitudes to leprosy}

The inbred fear of leprosy combined with the traditional belief in the supernatural cause of the 


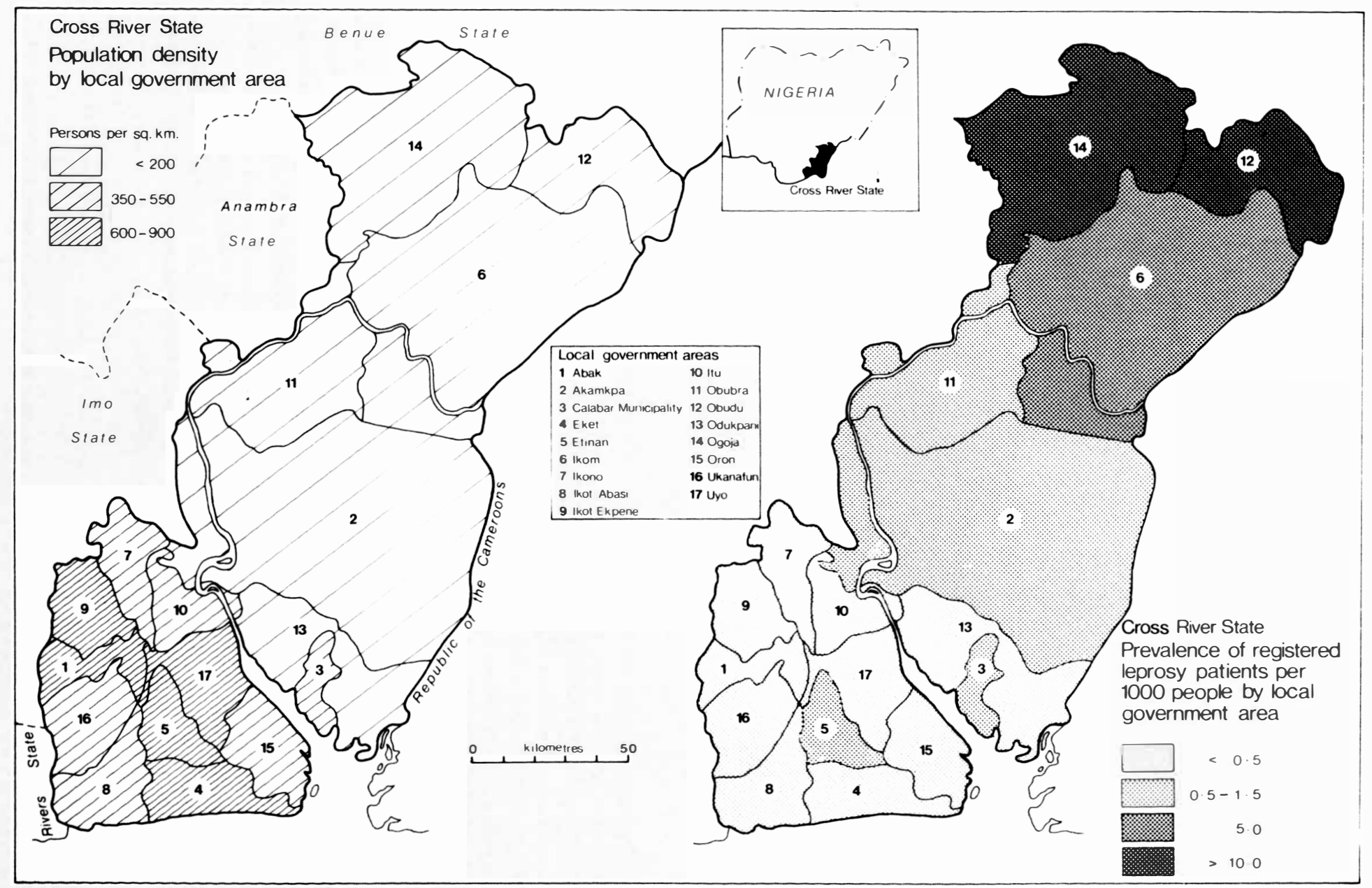

Figure 1. Note that neither population density nor leprosy prevalence rates for CRS are mapped in sequential uniform classes due to the nature of the data. 


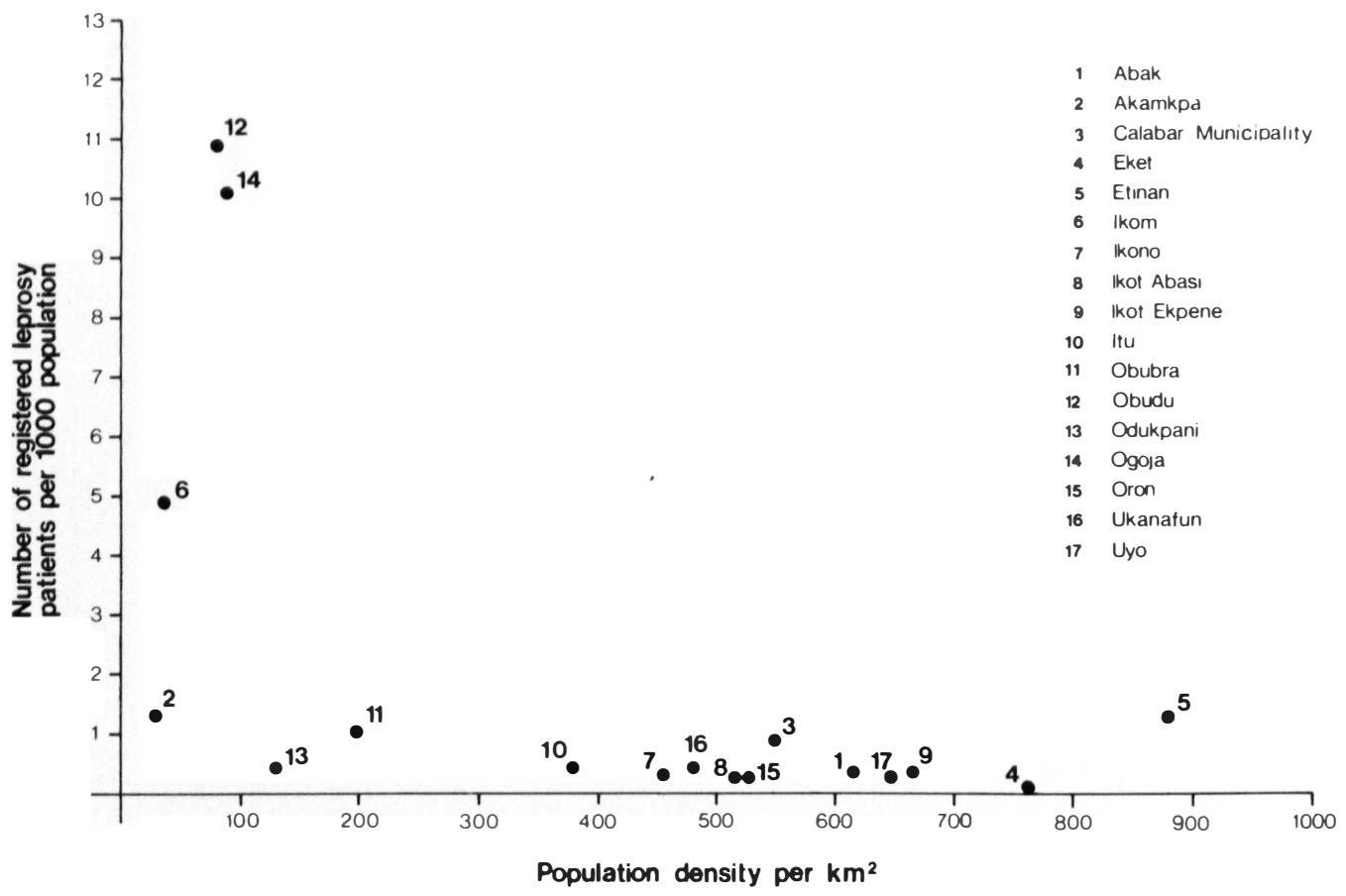

Figure 2. Prevalence of leprosy and population density by Local Government Area, 1984.

disease mean that it is severely stigmatized in CRS and this adversely affects the control programme in a number of ways. Frequently there is late reporting of new cases, the patient hiding the condition for as long as possible. By the time the case is reported many contacts may have been infected and the disease may have advanced in the patient to cause irreversable deformity. During this time the patient is likely to have been treated by native medicine which may have caused further injury, or the patient may have received treatment for skin conditions other than leprosy due to poor diagnosis. This reflects the low level of education with reference to leprosy both of paramedics and doctors, and is a cause for concern in some quarters in the State and has led to a compulsory leprosy module being recently introduced at the University of Calabar Medical School.

A second result of the prevailing attitude to leprosy is in poor patient compliance with therapy, once diagnosed. Two factors are involved here, in addition to the usual one of the long duration of treatment. For outpatients to make monthly clinic trips for drugs may be expensive in money and in time, especially during the season of intense agricultural activity. It may also lead to awkward questions being asked of a patient who wishes to hide the condition. The other factor relates to the patient's own perception of the cause of the disease which, in nearly every case interviewed, revealed a suspicion of witchcraft by a named jealous neighbour or relative. Enormous doubts can arise about the efficacy of the pills especially when you see or feel little change in your condition and when you believe someone intends you evil and has already called on the power of witchcraft to give you leprosy and sustain the condition by preventing the ulcer from healing, etc. Even when patients are shown evidence of bacilli numbers decreasing they are frequently sceptical. Doctors, nurses and leprosy control officers can become very disheartened with their patients' lack of cooperation.

The third result of the stigma attached to the disease is the effect it has on the staffing of the leprosy control service in the State, which is generally undermanned and under-resourced. Even the 
monthly salary supplement of 10 Naira (approximately $£ 5$ ) which is paid to all workers in leprosy (and TB) as 'danger money', does little to alleviate the problem. There are 136 medical doctors in government service in the State, mostly indigenous Nigerians, but the 4 doctors involved in leprosy work are all ex-patriates. (The medical course module in leprosy at the University of Calabar may remedy this situation for the future however.) Nevertheless, there are some highly dedicated workers who are committed to their patients even though they receive little encouragement thanks to the poor career structure, which at present offers them few incentives to remain in leprosy control work. But another staffing problem arising from stigma is the opportunity it provides for blackmail.

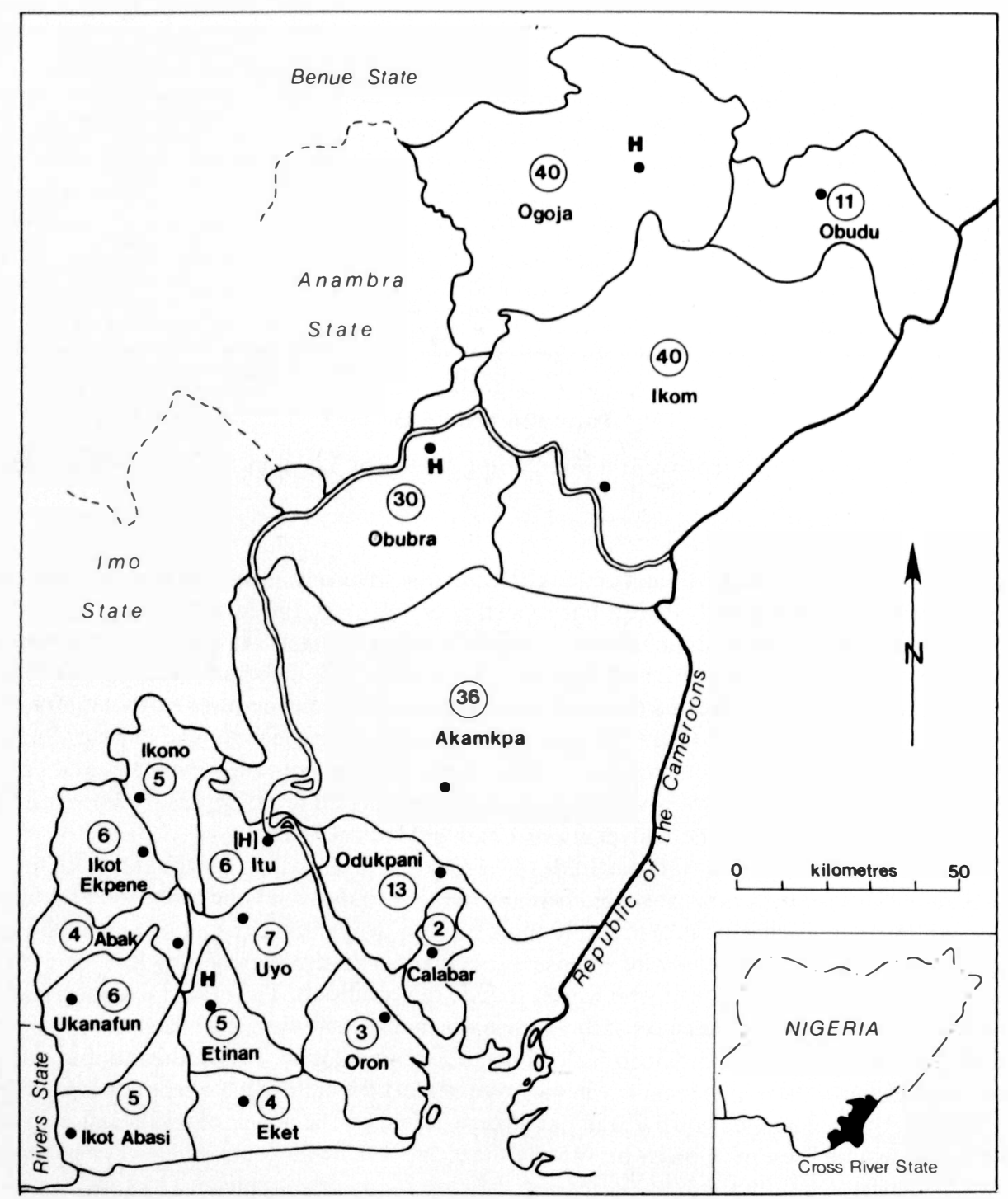

Figure 3. Cross River State: Leprosy Control Service. O, number of leprosy clinics in LGA; H, Leprosy hospital; •, LGA Headquarters: location of leprosy control unit; $(\mathrm{H})$, former leper colony at Itu (1928-68). 
Patients wishing to receive treatment but to conceal their disease may be forced to pay sums of money by unscrupulous control officers. As well as placing severe hardship on the patient, it may also prevent referral to a hospital of a case in need of special attention.

Only when the stigma against leprosy are removed by education of the public, the patients and the medical profession, will these three major constraints on the efficient operation of the leprosy control service in the State be eradicated.

\section{CRS Leprosy Control Service}

Leprosy was not recognized as a serious medical problem in CRS until 1926 when a Scottish missionary doctor at the General Hospital in Itu began to treat a few patients with hydnocarpus oil he obtained from India, the first doctor in Nigeria to do so. The famous missionary, Mary Slessor, had also cared for leprosy cases in this area earlier in the century. But after 1926 and the news of a treatment, cases appeared as if from nowhere and in the first 6 months 400 outpatients were under treatment with weekly injections. This led to the establishment in 1928 of the first African colony of leprosy patients. This was on a sandbank in the Cross River at Itu, a long established river port in the tropical forest, trading with Europe and also a centre of missionary activity. From the beginning there was a government grant supporting it, although it remained under the control of the Church of Scotland Mission, and during its existence received support from BELRA (now LEPRA), the Mission to Lepers (now the International Leprosy Mission) and Toc H. In 1928 suitable land was allocated by local chiefs and construction work began by the 800 patients. BELRA supplied the hydnocarpus oil from India and also supplied literature on leprosy and provided other help. By 1931 there were 1100 in-patients and several hundred outpatients. ${ }^{5}$

Hydnocarpus oil was the principal method of treatment until 1951 when every patient was put onto the sulphone treatment in addition. Some 28,000 were to receive treatment at Itu, an average 4300 patients each year before it was destroyed by bombs in Nigeria's civil war. Some former Itu patients and staff are to be found as staff in the existing 3 leprosy hospitals in the State and even further afield.

The It u Leprosy Colony became a model for colonies elsewhere in Nigeria and Africa and also revealed the seriousness of the leprosy problem in the area. Three more hospitals were to be established by European missions within the State (Figure 3, Table 2), and from the late 1930's and into the late 1950's a large number of segregated villages were established by local communities. All

\section{Table 2}

\begin{tabular}{|c|c|c|c|c|c|}
\hline $\begin{array}{l}\text { Hospital } \\
\text { location }\end{array}$ & Foundation & Date & Doctors & $\begin{array}{l}\text { Patient } \\
\text { beds }\end{array}$ & Facilities \\
\hline Etinan & Qua Iboc Mission & 1932 & 2 & 173 & $\begin{array}{l}\text { Lab., Theatre, } \\
\text { Shoemaker, } \\
\text { Limbmaker }\end{array}$ \\
\hline Mbembe, Obubra & Church of Scotland Mission & 1959 & weekly visit & 30 & $\begin{array}{l}\text { Lab., Shoemaker's } \\
\text { workshop unstaffed } \\
\text { since } 1984\end{array}$ \\
\hline Ogoja & Roman Catholic Mission & 1943 & I since 1985 & 63 & $\begin{array}{l}\text { Lab., Physio., } \\
\text { Shoemaker }\end{array}$ \\
\hline
\end{tabular}


Table 3. Cross River State: population density by local government area, 1984.

\begin{tabular}{clc}
\hline Rank & LGA & Density per km² \\
\hline 1. & Etinan & 880 \\
2 & Eket & 763 \\
3 & Ikot Ekpene & 664 \\
4 & Uyo & 648 \\
5 & Abak & 614 \\
6 & Calabar Municipality & 548 \\
7 & Oron & 526 \\
8 & Ikot Abasi & 517 \\
9 & Ukanafun & 479 \\
10 & Ikono & 451 \\
11 & Itu & 379 \\
12 & Obubra & 196 \\
13 & Odukpani & 129 \\
14 & Ogoja & 87 \\
15 & Obudu & 80 \\
16 & Ikom & 35 \\
17 & Akamkpa & 28 \\
\hline
\end{tabular}

of these are now officially abandoned but some became the site of a leprosy clinic and one became the Leprosy Hospital at Mbembe.

The current leprosy control service is administered by the State Ministry of Health from Calabar through the Leprosy Control Units located in the 17 LGA Headquarters (Figure 2) and in the 3 specialist leprosy hospitals. These all submit monthly and annual returns for the State and Federal Health Ministries and for UNICEF and the WHO. They also administer the leprosy clinics which are scattered throughout each LGA and which are mostly convened on a monthly basis for examination of new patients, distribution of drugs, discharges and referral to hospitals. Regular village, school and plantation surveys were also administered from these 17 Leprosy Control Units until the severe economic constraints which have damaged the whole control service especially since 1980.

\section{Reporting structure of Leprosy Control Services}

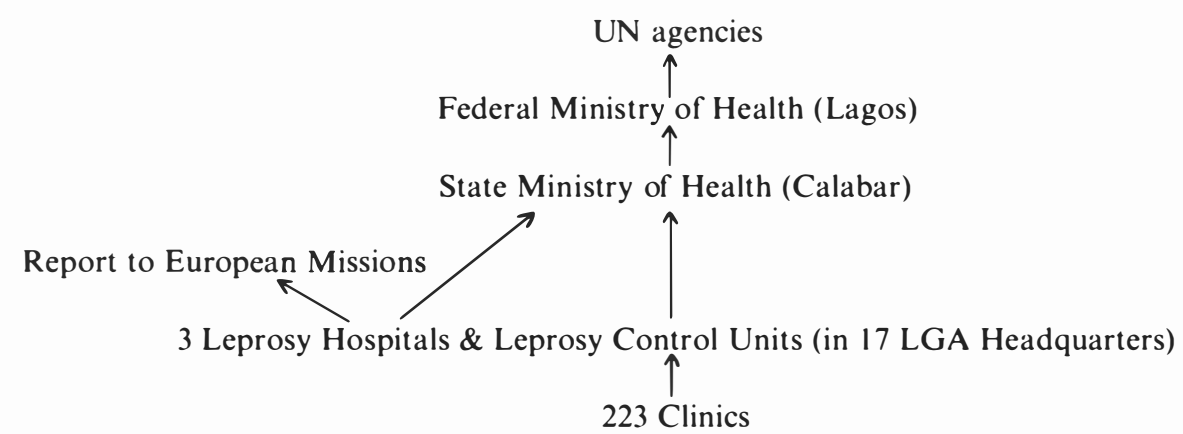


Outside the reporting structure there is also a Leprosy Advisory and Coordinating Committee, both at National level (inaugurated 1982) and 3 at regional level (the Eastern Zonal Committee dates back to 1980 and incorporates Cross River State). These Committees meet at regular intervals to plan strategies for leprosy control within their zones, and they organise training workshops. Recurrent themes in their deliberations include the issues of an inadequate supply of trained personnel, poor funding of the service and the problem of defaulters.

In each LGA headquarters there is a Leprosy Control Unit ideally staffed by one Leprosy Control Assistant and one Leprosy Control Attendant, but at the end of 1984 there were only 12 assistants and 11 attendants and since that date there have been further cutbacks in government employment which have affected the Service. The structure also provides for a State Consultant Leprologist but the post has never been filled.

The constraints on operating an effective leprosy control service at present are not a lack of administrative structure because that exists, as has been shown. The problems are lack of sufficient trained personnel and of transport for their movement from headquarters to clinics, and also frequent drug shortages. Lack of motor vehicles and spare parts, and of river boats means that in many LGA's the leprosy control personnel remain in headquarters, unable to visit regularly the monthly clinics or follow up defaulting patients or carry out surveys, and the consequences are that even when drugs are available they are not distributed. All of these have serious implications for the future of leprosy in the State.

During the colonial period and the early years of independence walking, bicycles and canoes were the main means of transport. Then came two events which changed the face of CRS: the Civil (Biafran) War 1967-70 which was centred here and in neighbouring states, then the subsequent oil boom. The Civil War seriously disrupted the smooth operation of the Leprosy Control service in the region, as well as destroying the hospital at Itu and scattering its patients. The oil boom helped Nigeria in the 1970's to recover from the economically devastating effects of the war. Roads were built, cars and motor cycles were imported, and with cheap fuel the use of bicycles declined. Therefore, resourcing a mobile unit of the medical service, which leprosy units must be in this rural state, became much more expensive. It has now become nearly impossible in the 1980's with the drop in oil prices which is ruining Nigeria's heavily oil-dependent economy. Thus, the leprosy control service of CRS is one more casualty of the world oil recession.

Transport problems explain the drugs shortage, especially the shortage of Dapsone. Medical supplies are available from Lagos, but there is no centralized distribution system. Each state in the Federation has a high degree of autonomy and is responsible for payment and collection of its own medical supplies. With a shortage of reliable vehicles, trips to Lagos $(800 \mathrm{~km})$ for supplies are erratic. Supplies of expensive drugs for MDT present yet another problem, and clofazimine especially was being reported to be in short supply in 1984, and subsequently.

\section{Conclusions and recommendations}

Leprosy control has a low priority in the State medical service, for many reasons. As has been shown it is short of staff and transport and a regular drug supply. The present vertical administrative structure is unlikely in the near future to receive the appropriate resources, especially transport, to enable it to function adequately in its task of finding new cases, providing the most appropriate treatment (such as multiple drug therapy) on a regular, supervised basis, and following up defaulters.

A fresh approach is required and it is suggested that this will contain at least three essential ingredients. These are, firstly, a massive education and re-education programme which will contribute to the destigmatization of the disease among all strata of society. People must also be convinced that leprosy can be cured and that early reporting is essential. Paramedics, medical 
doctors and native doctors (who have official recognition and registration in Nigeria) must become familiar with the diagnosis and treatment of the disease.

Secondly, a steady and reliable flow of all necessary drugs must be assured. A means must also be found of making the new multiple drug therapy more widely available and this will require the development of techniques to make it simple to administer.

The third component of a new approach must be the involvement of people at the village level. It may be that a new control strategy will depend upon educated people implementing it in their own communities through village meetings, surveys and with reference to existing medical services.

The leprosy problem in Cross River State is not insurmountable. The control of the disease and its eventual eradication only needs some fresh thinking and commitment.

\section{Acknowledgments}

I am grateful to LEPRA, to The Nuffield Foundation and to The Britain-Nigeria Association for financial support to enable me to conduct fieldwork in Nigeria. However, the work would not have been possible without the excellent and willing co-operation and encouragement of medical workers and leprosy patients in Nigeria. I thank them all for their help.

\section{References}

1 Population Bulletin 1980-83. Statistics Division, Ministry of Economic Planning, Calabar, 1980.

2 Damien Foundation. Atlas of Leprosy. Brussels, 1979.

3 De Plantes MZ. Informal Report of WHO visit to Cross River State, February 1983.

${ }^{4}$ Hunter JM, Thomas MO. Hypothesis of leprosy, Tuberculosis and Urbanisation in Africa. Soc Sci Med, 1984; Vol. 19, No. 1, 22-57.

${ }^{5}$ Macdonald AB. Can Ghosts Arise: the Answer of Itu. Edinburgh, 1957. 